\title{
ヘッドスペース法を用いる食品中の残留塩素の定量
}

\author{
(昭和 60 年 4 月 19 日受理)
}

$\begin{array}{lll}\text { 日高利夫* } & \text { 田 中 康夫* } & \text { 中村香代子* } \\ \text { 宝井辰 紀* } & \text { 桐ヶ谷忠司* } & \text { 上條昌 弥* } \\ \text { 鈴木 幸 夫* } & \text { 河 村 太郎* } & \end{array}$

\section{Determination of Residual Chlorine in Foods by Head Space Gas Chromatography}

\section{Toshio Hidaka, Yasuo Tanaka, Kayoko Nakamura, Tatsutoshi Takarai, Tadashi Kirigaya, Masaya Kamijo, Yukio Suzuki and Taro KaWamura}

(Yokohama City Institute of Health: 1-2-17, Takigashira, Isogo-ku, Yokohama, Japan)

An analytical method was developed for quantitative determination of residual chlorine in foods using head space gas chromatography.

The principles of the proposed method are as follows. Phosphate buffer solution of pH 7.0 and potassium cyanide solution were placed in a vessel for head space analysis, a sample was added, and the resultant mixture was left standing in the vessel (covered with a lid) for 30 minutes. Cyanogen chloride formed therein was determined by ECD-GC. The values of residual chlorine in tap water measured by the present method were compared with those obtained by the $o$-tolidine colorimetric method. The respective values were quite consistent. The determination limit was $0.1 \mu \mathrm{g} / \mathrm{g}$.

Analysis of 67 specimens of vegetables and processed fish and shellfish products available in the market revealed $14.0 \mu \mathrm{g} / \mathrm{g}$ and $11.6 \mu \mathrm{g} / \mathrm{g}$ of residual chlorine in two specimens of soybean sprouts.

$$
\text { (Received April 19, 1985) }
$$

Key words: ヘッドスペース法 head space method; ガスクロマトグラフィー (ECD) gas chromatography (ECD); 残留塩素 (食品中) residual chlorine (in foods); 塩化シアン cyanogen chloride

\section{まえがき}

次亜塩素酸, 次亜塩素酸ナトリウム，サラシ粉及び高 度サラシ粉は魚介類加工品, 野菜類の漂白, 殺菌, さら には食品製造加工に使用する装置，器具などの殺菌，消 毒に使用されている，ところが，これらに由来する食品 中の残留塩素の定量法については報告が見当らない.

従来より用いられている残留塩素の定量法として, ヨ ウ素滴定法 ${ }^{1)}$ 及びo・トリジンによる比色法 ${ }^{2)}$ があるが， これらの方法は検出感度並びに妨害物質による影響など の点で食品中の残留塩素の定量法として適当でない.
そこで, 著者らは残留塩素を密封容器内でシアンと反 応させ, ここに生成する塩化シアンを電子捕獲型検出器 付きガスクロクトグラフ (ECD.GC) により定量する方 法について検討し，市販食品に応用したところ，良好な 結果を得ることができたので報告する。

\section{実験方法}

\section{1. 試料}

昭和56年 2 月に横浜市内で市販された野菜類, 魚介類 加工品, 魚肉袨品など Table 2 に示した 67 検体を 用いた。

* 横浜市衛生研究所：横浜市磯子区滝頭 1-2-17 


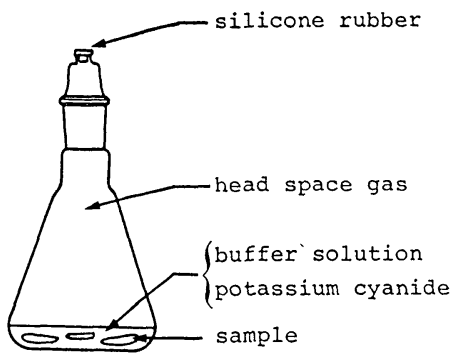

Fig. 1. Head space analysis vessel Sample size: $2.0 \mathrm{~g}$ of food Vessel volume: $200 \mathrm{ml}$

\section{2. 試薬}

1)水：イオン交換水を用いた.

2) シアン化カリウム溶液：シアン化カリウム $0.10 \mathrm{~g}$ に水を加えて $1,000 \mathrm{ml}$ として用いた。

3) $\mathrm{pH} 1.0 \sim 12.0$ 緩衝液：Merck 社製濃縮緩衝液 (Puffer-Titrisol $囚$ ) pH 1.0〜12.0のそれぞれを水で $500 \mathrm{ml}$ に希釈して用いた。

リン酸塩緩衝液 (pH 7.0) の組成はリン酸一カリウム $3.522 \mathrm{~g}$ 及びリン酸二ナトリウム (2 水塩) $7.265 \mathrm{~g}$ を水 に溶かして $1,000 \mathrm{ml}$ としたものである.

4）塩素標準液：あらかじめヨウ素滴定法1)で定量し た次亜塩素酸ナトリウム液 $(2.65 \%$ 含有) $1.0 \mathrm{ml}$ をメ スフラスコにとり，水を加えて正確に $100 \mathrm{ml}$ として標 準原液とした. 用時, 標準原液 $5.0 \mathrm{ml}$ を正確にメスフ ラスコにとり，水を加えて全量を $50 \mathrm{ml}$ として塩素標 準液とした. 本液 $1 \mathrm{ml}$ は有効塩素 $26.5 \mu \mathrm{g}$ を含有す る.

以上, シアン化カリウムは和光純薬工業(株)製, 試薬 特級を，また，次亜塩素酸ナトリウム液は同じく食品添 加物用を用いた。

\section{3. 装置及び測定条件}

1）ヘッドスペース用フラスコ：200 ml の共通摺合 せ三角フラスコ及びこの栓として共通摺合せ連結管の上 部を切断してシリコンゴム（ガスクロマトグラフの注入
口用のもの）を付したものを用いた（Fig．1)

2） ガスクロマトグラフ (GC):（株）島津製作所製

GC-6 A (検出器 $\mathrm{ECD}{ }^{63} \mathrm{Ni} 10 \mathrm{mCi}$ )

充てん剂: TENAX-GC

カラム管： $3 \mathrm{~mm} \phi \times 1 \mathrm{~m}$ ガラス製

カラム温度： $80^{\circ}$

注入口温度： $150^{\circ}$

キャリアーガス: $\mathrm{N}_{2} 20 \mathrm{ml} / \mathrm{min}$

3) ガスクロマト質量分析計 (GC-MS) 及びデータ処

理装置：(株) 日立製作所製 M-80 型及び M-003 型

充てん剤: TENAX-GC

カラム管: $3 \mathrm{~mm} \phi \times 1 \mathrm{~m}$ ガラス製

カラム温度: $80^{\circ}$

注入口温度： $150^{\circ}$

セパレーター温度： $280^{\circ}$

イオン源温度： $180^{\circ}$

イオン化電圧： $20 \mathrm{eV}$

イオン電流: $100 \mu \mathrm{A}$

キャリアーガス: He $20 \mathrm{ml} / \mathrm{min}$

以上, ヘッドスペース用フラスコ及び GC 条件は衛生 試験法のヘッドスペース法による塩化シアンの定量 ${ }^{3)} に$

準じた。

なお，ガラス器具及びその他の器具類は水道水由来の 残留塩素による影響を防ぐため, 十分水で洗浄後, 乾燥 したものを用いた。

\section{4. 試料の調製及び定量操作}

1) 試料の調製

検体より一部分を切りとり, 細切あるいは粉砕するこ とを極力さけて試料とした。

2) 定量操作

あらかじめ, リン酸塩緩衝液（pH 7.0) $20 \mathrm{ml}$ 及びシ アン化カリウム溶液 $1.0 \mathrm{ml}$ を入れたへッドスペース用 フラスコに，切りとった試料 $2.0 \mathrm{~g}$ を加えた後，ただち に栓をして30分間放置する。このへッドスペース用フラ スコ中のガス $10 \mu 1$ をガスタイトシリンジを用いて ECD-GC に注入し，同時に作成した検量線から食品中 の残留塩素を定量した。

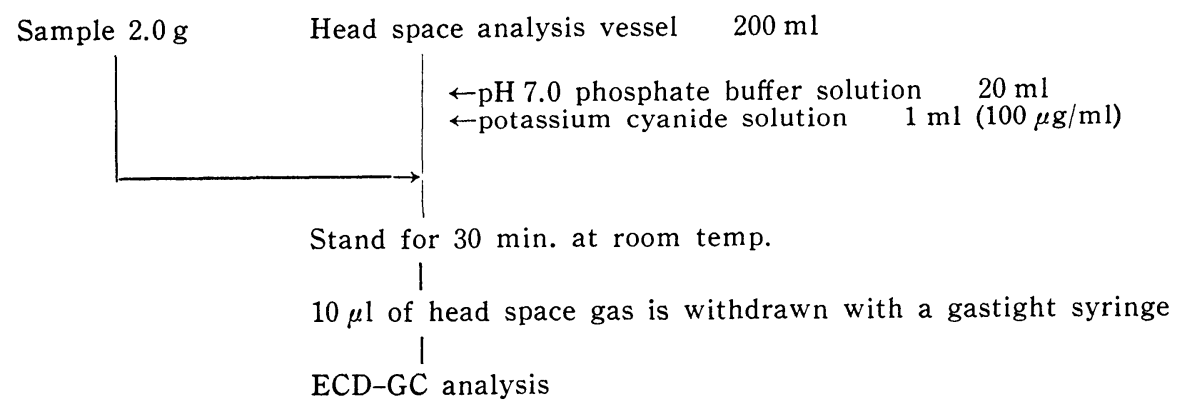

Scheme 1. Analytical procedure for residual chlorine in foods 


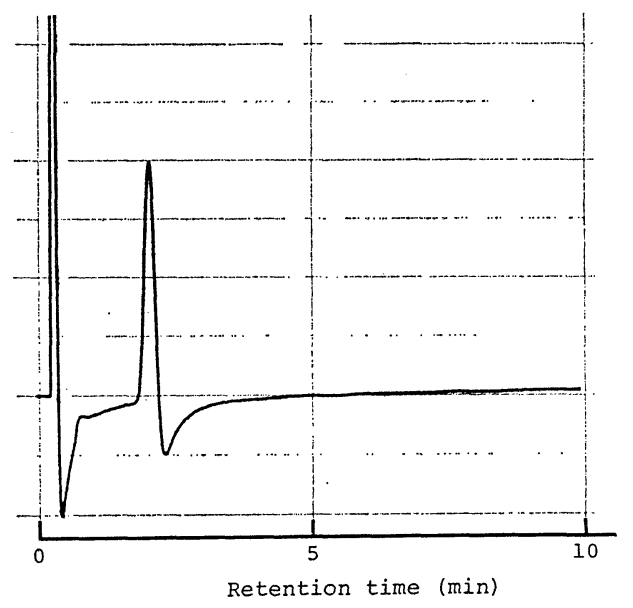

Fig. 2. Gas chromatogram (ECD) of the reaction product

Conditions, column: TENAX-GC $(60 \sim$ $80 \mathrm{mesh}), \quad 3 \mathrm{~mm} \phi \times 1 \mathrm{~m}$; column temp.: $80^{\circ} \mathrm{C}$; det. temp.: $150^{\circ} \mathrm{C}$; inj. temp.: 150 ${ }^{\circ} \mathrm{C}$; carrier gas: $\mathrm{N}_{2} 20 \mathrm{ml} / \mathrm{min}$ Chlorine: $5.3 \mu \mathrm{g} /$ vessel

\section{3）検量線の作成}

塩素標準液 $0.5 \mathrm{ml}, 1.0 \mathrm{ml}, 2.0 \mathrm{ml}$ 及び $3.0 \mathrm{ml}$ を正 確にメスフラスコにとり，それぞれに水を加えて全量を $20 \mathrm{ml}$ とする.この $2.0 \mathrm{ml}$ をそれぞれ試料の場合と同 様に操作して，ピーク高さにより検量線を作成した。

\section{試験操作の概略を Scheme 1 に示した.}

\section{実験結果及び考察}

\section{1. 反応生成物の $\mathbf{G C}$ と同定}

塩素 $5.3 \mu \mathrm{g}$ 相当量から得られた試験ガス中の反応生 成物のガスクロマトグラムを Fig. 2 に示した. ガス クロマトグラム上には反応生成物の単一ピークが保持時 間，約 2 分後に認められた.
また，この反応生成物を同定するため, 試験ガスを GC-MS に供し, 得られたピークのマススペクトルを測 定したところ, Fig. 3 に示すような結果が得られた。 マ ススペクトル上には塩化シアンの分子イオン及びその同 位体として $\mathrm{m} / \mathrm{z} 61, \mathrm{~m} / \mathrm{z} 63$ のピーク，さらにフラグメ ントイオンとしてシアンの $\mathrm{m} / \mathrm{z} 26$, 塩素及びその同位 体の $\mathrm{m} / \mathrm{z} 35, \mathrm{~m} / \mathrm{z} 37$ のピークが認められ, 反応生成物 は塩化シアンと同定された。

\section{2. 試料の調製方法の検討}

食品中の残留塩素は試料調製の際，食品成分と反応す る可能性がある.そこで試料の調製方法について検討を 行った.

検討に当っては, あらかじめ $20 \mathrm{ppm}$ の次亜塩素酸ナ トリウム液 $3.5 \mathrm{~L}$ でキャベッ及びもやしを10分間浸漬 し，次にこのキャベッ及びもやしより，それぞれ原形の ままの試料, 約 $5 \mathrm{~mm}$ 幅に細切した試料, すりばちで 潰した試料を調製した．そして，ここに得た 6 種類の試 料のそれぞれについて, Scheme 1 に示した操作を10回 ずつ行い残留塩素量を測定した.この結果は Table 1 に示すように，キャベッの平均残留塩素量は原形のまま の試料で $0.8 \mathrm{ppm}$ ，細切した試料で $0.2 \mathrm{ppm}$ の值を示 し，潰した試料では定量限界以下であった。また，るや しの平均残留塩素量は原形のままの試料で, $10.4 \mathrm{ppm}$, 細切した試料で $3.1 \mathrm{ppm}$, 潰した試料では $1.0 \mathrm{ppm} の$ 值を示した。

以上の結果は, 食品を細切あるいは潰すほど残留塩素 が分解することを示唆しており，試料の調製の際にはこ の点を十分留意する必要がある，そこで，試料の調製方 法としては，検体より一部分を切りとり，細切あるいは 粉碎することを極力さけて試料とした。

\section{3. 定量操作の検討}

塩化シアンを生成する操作手順として，ヘッドスペー ス用フラスコに残留塩素を含む試料及びリン酸塩緩衝液 を入れ，これにシアン化カリウム溶液を加えた場合，塩

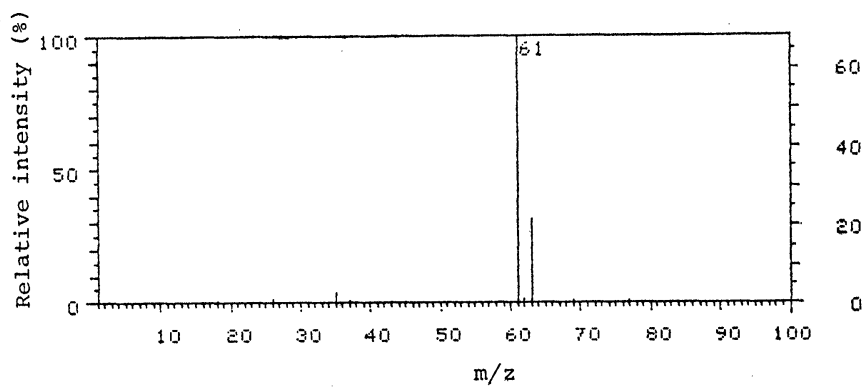

Fig. 3. Mass spectrum of the reaction product (cyanogen chloride)

Conditions, column: TENAX-GC $(60 \sim 80 \mathrm{mesh}), 3 \mathrm{~mm} \phi \times 1 \mathrm{~m}$; column temp.: $80^{\circ} \mathrm{C}$; inj. temp.: $150^{\circ} \mathrm{C}$; separator temp.: $280^{\circ} \mathrm{C}$; ion source temp.: $180^{\circ} \mathrm{C}$; electron energy: $20 \mathrm{eV}$; ion current: $100 \mu \mathrm{A}$; carrier gas: $\mathrm{He} 20 \mathrm{ml} / \mathrm{min}$ 
Table 1. Results of Comparative Analyses of Residual Chlorine in Samples Prepared by Three Different Ways

\begin{tabular}{lc}
\hline \multicolumn{1}{c}{ Samples $^{\mathrm{a}}$ ( } & $\begin{array}{c}\text { Residual chlorine } \\
(\mathrm{ppm})\end{array}$ \\
\hline Cut cabbage leaves & 0.8 \\
Chopped cabbage leaves & 0.2 \\
Crushed cabbage leaves & $\mathrm{ND}$ \\
\hline Cut soybean sprouts & 10.4 \\
Chopped soybean sprouts & 3.1 \\
Crushed soybean sprouts & 1.0 \\
\hline
\end{tabular}

a) These samples were previously soaked in $3.5 \mathrm{~L}$ of $\mathrm{NaClO} 20 \mathrm{ppm}$ solution for $10 \mathrm{~min}$ utes.

b) These values were averages of 10 experiments.

ND: not detected

化シアンの生成が抑制された。これは試料にリン酸塩緩 衝液を加える際, 残留塩素が食品成分と反応するためと 考えられた. そこで，ヘッドスペース用フラスコにリン 酸塩緩衝液及びシアン化カリウム溶液を入れ, 最後に試
料を加えることとした.

\section{4. 塩化シアンの生成と $\mathrm{pH}$ の関係}

pH 1.0 12.0 の緩衝液 $20 \mathrm{ml}$ を入れたそれぞれのへ ッドスペース用フラスコに，シアン化カリウム溶液 1.0 $\mathrm{ml}$ 及び塩素 $8 \mu \mathrm{g}$ 相当量を加え, $0.5,1.5,4.5$ 及び 22.0 時間後に測定した結果を Fig. 4 に示した. 30 分 後には, pH 5.0〜9.0 の範囲の緩衝液で塩化シアンが良 好に生成した。 また，経時的変化についてみると， $\mathrm{pH}$ 7.0 及び $\mathrm{pH} 8.0$ の緩衝液は 4 時間30分後まで塩化シア ンの変化がほとんど認められず, 安定であった。

\section{5. 塩化シアンの生成とシアン化カリウム量}

塩素とシアンはモル比 $1: 1$ で反応し, 塩素 $8 \mu \mathrm{g}$ に対 応するシアン化カリウム量は $15.1 \mu \mathrm{g}$ である. しかし, 塩化シアンが短時間で十分生成するためには, 過剰のシ アン化カリウムを加えるほらがよい，そこで，30分後に 生成する塩化シアンとそれに要するシアン化カリウム量 との関係を, 塩素 $8 \mu \mathrm{g}$ を用いて調べ, Fig. 5 に示した. その結果, シアン化カリウム量は $\mathrm{pH} 7.0$ の緩衝液で $50 \mu \mathrm{g}$ 以上, $\mathrm{pH} 8.0$ の緩衝液で $100 \mu \mathrm{g}$ 以上存在すれ ば, 30 分後に塩化シアンが十分生成することがわかっ た.

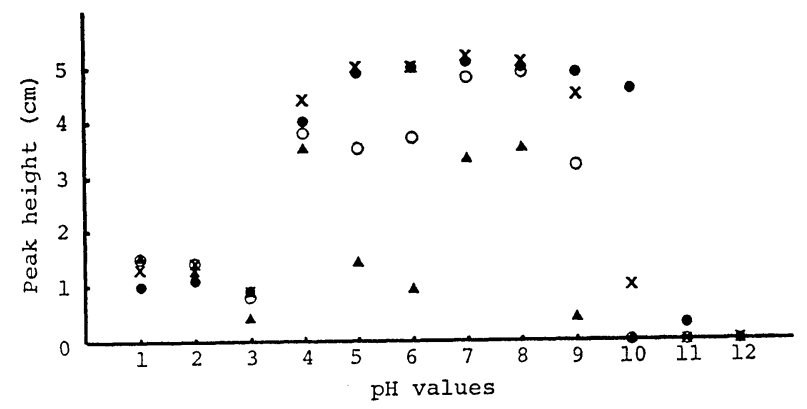

Fig. 4. Formation and stability of cyanogen chloride at different $\mathrm{pH}$ values ๑: $0.5 \mathrm{hr}$; $\times$ : $1.5 \mathrm{hr}$; $0: 4.5 \mathrm{hr}$; $\Delta: 22.0 \mathrm{hr}$; chlorine: $8 \mu \mathrm{g} /$ vessel

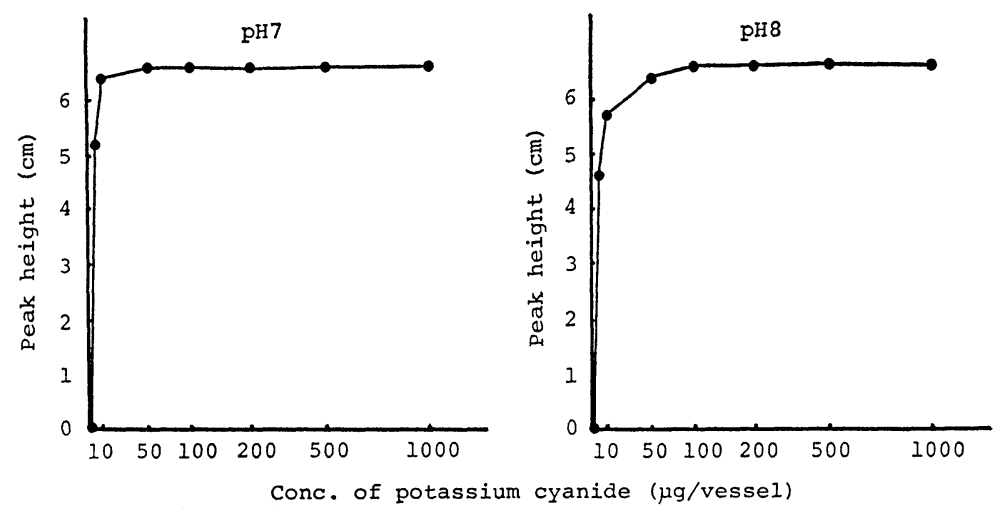

Fig. 5. Effect of potassium cyanide concentration on cyanogen chloride formation Chlorine: $8 \mu \mathrm{g} /$ vessel 


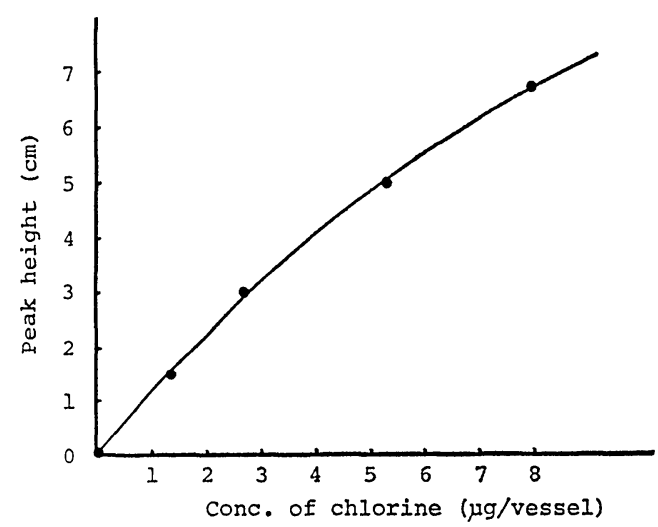

Fig. 6. Calibration curve of chlorine

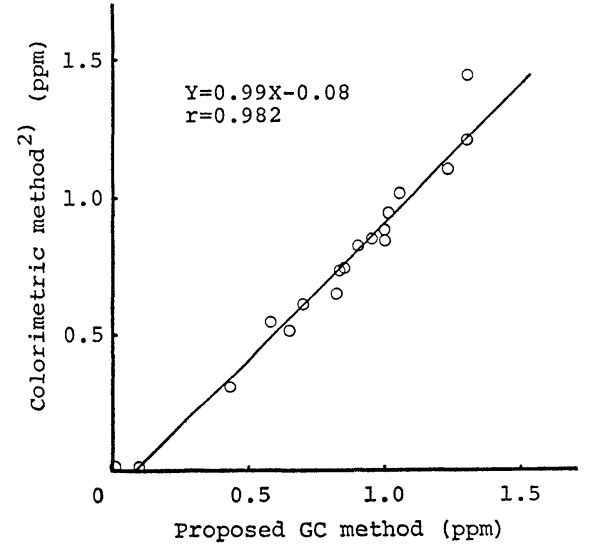

Fig. 7. Relationship of residual chlorine in tap water determined by colorimetric and proposed GC method

Table 2. Analytical Results of Residual Chlorine in Foods

\begin{tabular}{|c|c|c|c|}
\hline Samples & $\begin{array}{c}\text { Number of } \\
\text { samples }\end{array}$ & $\begin{array}{c}\text { Number of } \\
\text { detected }\end{array}$ & $\begin{array}{c}\text { Residual chlorine } \\
(\mu \mathrm{g} / \mathrm{g})\end{array}$ \\
\hline \multicolumn{4}{|l|}{ Vegetables } \\
\hline Lettuce & 2 & 0 & ND \\
\hline Cabbage & 3 & 0 & ND \\
\hline Soybean sprouts & 10 & 2 & $14.0,11.6$ \\
\hline Other vegetables & 8 & 0 & ND \\
\hline \multicolumn{4}{|l|}{ Fungi } \\
\hline $\begin{array}{l}\text { Flammulina velutipes } \\
\text { (Enokidake) }\end{array}$ & 2 & 0 & $\mathrm{ND}$ \\
\hline $\begin{array}{l}\text { Tricholoma shimeji } \\
\quad \text { (Shimeji) }\end{array}$ & 1 & 0 & ND \\
\hline $\begin{array}{l}\text { Pholiota nameko } \\
\text { (Nameko) }\end{array}$ & 1 & 0 & $\mathrm{ND}$ \\
\hline \multicolumn{4}{|l|}{ Seaweeds } \\
\hline $\begin{array}{l}\text { Nemacystus decipiens } \\
\text { (Mozuku) }\end{array}$ & 1 & 0 & ND \\
\hline $\begin{array}{l}\text { Undaria pinnatifida } \\
\text { (Wakame) }\end{array}$ & 1 & 0 & ND \\
\hline \multicolumn{4}{|c|}{ Processed fishes and shellfishes } \\
\hline Jellyfish & 3 & 0 & ND \\
\hline Herring roe & 3 & 0 & ND \\
\hline Squid & 3 & 0 & ND \\
\hline Abalone & 1 & 0 & ND \\
\hline \multicolumn{4}{|l|}{ Fish paste products } \\
\hline Kamaboko & 25 & 0 & $\mathrm{ND}$ \\
\hline Naruto & 3 & 0 & ND \\
\hline Total & 67 & 2 & \\
\hline
\end{tabular}

ND: not detected 
これらのことより，緩衝液にはシアン化カリウム量が 少量でよい $\mathrm{pH} 7.0$ のリン酸塩緩衝液を用いることと し，また，使用するシアン化カリウム量は試料中の残留 塩素の多い場合を考慮して $100 \mu \mathrm{g}$ とした.

\section{6. 検 量 線}

検量線は Fig. 6 亿示したように，原点を通るがわず かに曲線となった。

\section{7. 比色法との比較}

食品中の残留塩素を比色法 ${ }^{22}$ に上り測定したところ， 比色法では抽出操作の際に残留塩素が食品成分と反応す るため，正確な定量值を得ることが困難であった．とこ で今回は，水道水18検体について本法と比色法により残 留塩素を定量し, 両方法を比較した. この結果は Fig. 7 に示すように，両方法による定量值は良く一致した。

な㸱, 水道水 $2 \mathrm{~g}$ を用いた場合の本法による残留塩素 の定量限界は $0.1 \mu \mathrm{g} / \mathrm{g}$ であった.

\section{8. 市販食品中の残留塩素の定量}

本法を用いて，市販の野菜類及び魚介類加工品など 67 検体について残留塩素を定量した．この結果は Table 2 に示すように，もやしの 2 検体より残留塩素がそれぞれ $14.0 \mu \mathrm{g} / \mathrm{g}$ 及び $11.6 \mu \mathrm{g} / \mathrm{g}$ 検出された. しかし, その他 の製品から残留塩素は検出されなかった，特に，魚介類 加工品及び魚肉祀り製品に合成殺菌剂（次亜塩素酸ナト リウム) 使用といら表示のなされていた製品が 2, 3 みら れたが，これらの製品からも残留塩素は検出されなかっ た.

なお，検查を行った市販品については，塩化シアンの ピークを妨害する物質並びに類似ピークの出現する物質 は認められなかった。

\section{まと め}

次亜塩素酸, 次亜塩素酸ナトリウム, サラシ粉及び高
度サラシ粉に由来する食品中の残留塩素を定量する目的 で, ヘッドスペース法による分析法の検討を行った.

1）残留塩素とシアン化カリウムから生成する物質は GC-MS により塩化シアンと同定された.

2）試料の調製方法として，検体より一部分を切りと る方法を行った結果, 調製の際の残留塩素の損失を少な くすることができた.

3）定量操作及び条件を検討した結果， $\mathrm{pH} 7.0$ のリ ン酸塩緩衝液 $20 \mathrm{ml}$ 及びシアン化カリウム溶液 $1.0 \mathrm{ml}$ をへッドスペース用フラスコに入れ，最後に試料を加兄 る方法が塩化シアン生成の最適条件であった.

4）本法による水道水を試料とした定量值は， $o$-トリ ジンによる比色法の值と良く一致し, 定量限界は 0.1 $\mu \mathrm{g} / \mathrm{g}$ であった.

5）本法を用いて，市販の野菜類及び魚介類加工品な ぞ 67 検体について分析した結果, もやし 2 検体より $14.0 \mu \mathrm{g} / \mathrm{g}$ 及び $11.6 \mu \mathrm{g} / \mathrm{g}$ の残留塩素が検出された.

以上の結果, 本法は食品中の残留塩素の定量法として 十分適用できると思われる.

本調查研究の一部は, 昭和55年度厚生省食品添加物標 準分析法試験調查委託費により行った。

\section{文献}

1）食品添加物公定書注解編集委員会編： “第三版食 品添加物公定書注解” p. 356 358（1974） 金原 出版.

2) 日本薬学会編：“衛生試験法・注解” p. 746 748 (1980) 金原出版.

3）日本薬学会編：同上. p. $446 \sim 452 （ 1980 ）$ 金原 出版. 